\title{
Effectiveness of Agrochemicals on Development of Diseases during Reproductive Phase in Paddy
}

\author{
Ramabhadra Raju Mudunuri and M. R. B. Raju* \\ Plant Pathology Section, Agricultural Research Station, Ragolu (Acharya N G Ranga \\ Agricultural University), Srikakulam District - 532484, Andhra Pradesh, India \\ *Corresponding author
}

\begin{abstract}
A B S T R A C T
Keywords

Rice, Sheath rot, Brown spot, Grain discoloration, Benefit cost ratio, Reproductive stage, Fungicides

Article Info

Accepted:

04 September 2020

Available Online:

10 October 2020

A two year field study was conducted at Agricultural Research station, Ragolu to study the efficacy of selected agrochemicals on the development of diseases (sheath rot, brown spot and grain discolouration) during reproductive phase in paddy. Treatments were imposed for two times, once at $50 \%$ panicle emergence and 15 days subsequently. Among the fungicides, foliar application of propiconazole @ $1 \mathrm{ml} / \mathrm{L}$ was found most effective in minimizing the development of sheath rot $(5.9 \%)$, brown spot $(8.8 \%)$ and grain discoloration (7.4\%) in comparison to 27.0, 25.8 and 10.9 percent disease incidence respectively recorded in untreated control. The treatment was found to be statistically at par with trifloxystrobin + tebuconazole @ $0.4 \mathrm{~g} / \mathrm{L}$ and carbendazim $(1 \mathrm{~g} / \mathrm{L})$. Benefit cost ratio of 1.5:1 was realized in propiconazole and trifloxystrobin + tebuconazole treatments. The ineffectiveness of antibiotic treatment (streptomycin sulphate + tetracycline) suggests the predominant role of fungal pathogens in the development of sheath rot symptoms. The study emphasizes the importance of timely chemical interventions in minimizing disease load and maximizing returns in paddy.
\end{abstract}

\section{Introduction}

Rice (Oryza sativa L.) is the major crop under rainfed conditions of the north coastal zone of Andhra Pradesh. Paddy yields in this part of India are governed by the rainfall distribution and successful management of biotic constraints during the crop season. During reproductive phase in paddy, a number of diseases viz., sheath rot, neck blast, leaf spots etc. are responsible for causing significant damage to the crop viz., partial emergence of panicle, partial or total chaffiness of grains, grain discoloration, and in some instances loss of seed viability (Sumangala et al., 2011; Gopalakrishnan et al., 2010). Under ideal climatic conditions, disease problems during reproductive phase could cause significant damage to the crop (Sakthivel, 2001). Timely management of diseases during reproductive phase is of paramount importance in realising quality harvest. Literature suggests the use of fungicides, botanicals and bioagents for the management of individual diseases during reproductive phase viz., sheath rot, leaf spots, neck blast etc., (Kumar and Kumar 2012; 
Meera and Balabaskar, 2012; Sharma et al., 2013; Sarkar et al., 2014). However, information on comprehensive management of possible pathogens responsible for loss in grain yield and quality is lacking. Keeping in view, the potential losses caused by pathogens infecting paddy at panicle emergence to harvesting stage, present study was undertaken to evaluate agrochemicals against pathogens influencing seed health and yields in paddy.

\section{Materials and Methods}

A two year field trial was conducted at Agricultural Research Station, Ragolu (Acharya N G Ranga Agricultural University) during kharif 2011-13 in F. No. 13-IIB to evaluate the efficacy of nine selected agrochemicals (carbendazim, mancozeb, trifloxystrobin + tebuconazole, propiconazole, metiram, tebuconazole, metiram and streptomycin sulphate + tetracycline)against development of diseases during reproductive phase.

The experiment was laid out in Randomized block design with a plot size of $12.54 \mathrm{~m}^{2}$ and spacing of $20 \mathrm{x} 15 \mathrm{~cm}$, each treatment was replicated thrice. Standard package of practices (120-60-40 kg/ha NPK) were adopted during the trial. Locally popular, high yielding and neck blast resistant variety, RGL 2537 (Srikakulam Sannalu) was used as test variety. Treatment imposition (foliar spray) of individual agrochemicals at their recommended dosage was carried out for two times, first at $50 \%$ panicle emergence and second spray 15 days later. Foliar spray of water constituted untreated control.

Observations on the development of sheath rot, brown spot and grain discoloration were recorded periodically and expressed as percent disease incidence (Standard Evaluation System for Rice, IRRI 1996).
Arc sine transformation of data was done for statistical analysis. Pooled mean of data for two years was done and presented. Yield was expressed as $\mathrm{Kg} / \mathrm{ha}$. Total cost of cultivation, total returns and benefit cost ratio was calculated and presented.

\section{Results and Discussion}

In the field trail conducted for two years i.e., kharif 2011-12 and 2012-13 to study the efficacy of nine agrochemicals on the management of diseases during reproductive phase in paddy, foliar spray with the selected agrochemical at the recommended dosage was done at $50 \%$ panicle emergence and at 15 days after the first spray.

Treatments were imposed during afternoon hours for preventing disruption in fertilization. During the study, it was observed that mean sheath rot incidence in untreated control was comparatively higher $(35.5 \%)$ in 2012-13 compared to $18.8 \%$ incidence recorded during 2011-12 (Table 1). It is evident from Table 3 that higher rainfall recorded during November 2012 coincided with flowering in paddy, which could have resulted in comparatively more sheath rot incidence. Similarly, mean grain discoloration was higher in 2012-13 (17.6\%) compared to 2011-12 (4.2\%).

Among the individual treatments against sheath rot, trifloxytstrobin + tebuconazole was the most effective treatment recording pooled mean sheath rot incidence of $7.7 \%$, statistically at par with propiconazole and carbendazim. Antibiotic (streptomycin sulphate + tetracycline) treatment recorded a pooled mean sheath incidence of $19.2 \%$ in comparison to $24.2 \%$ recorded in untreated control. The ineffectiveness of antibiotic treatment suggests the predominant role of fungal pathogens in the development of sheath rot symptoms. 
Table.1 Effect of selected fungicides on the development of diseases during reproductive phase in paddy (two year study - 2011-13)

\begin{tabular}{|c|c|c|c|c|c|c|c|c|c|c|c|}
\hline \multirow{3}{*}{$\begin{array}{l}\text { S. } \\
\text { No. }\end{array}$} & \multirow[t]{3}{*}{ Treatment } & \multirow{3}{*}{$\begin{array}{l}\text { Dose } \\
\text { (g/l) }\end{array}$} & \multicolumn{9}{|c|}{ Per cent Incidence } \\
\hline & & & \multicolumn{3}{|c|}{ Sheath rot } & \multicolumn{3}{|c|}{ Brown spot } & \multicolumn{3}{|c|}{ Grain Discoloration } \\
\hline & & & 2011-12 & 2012-13 & $\begin{array}{l}\text { Pooled } \\
\text { Mean }^{+}\end{array}$ & 2011-12 & 2012-13 & $\begin{array}{l}\text { Pooled } \\
\text { Mean }\end{array}$ & 2011-12 & 2012-13 & $\begin{array}{l}\text { Pooled } \\
\text { Mean }\end{array}$ \\
\hline 1 & Carbendazim 50\%WP & 1 & $\begin{array}{c}5.0 \\
(12.9)^{*}\end{array}$ & $\begin{array}{c}10.0 \\
(18.4)\end{array}$ & $\begin{array}{c}7.5 \\
(15.7)\end{array}$ & $\begin{array}{c}9.5 \\
(17.9)\end{array}$ & $\begin{array}{c}14.6 \\
(22.4)\end{array}$ & $\begin{array}{c}12.1 \\
(20.2)\end{array}$ & $\begin{array}{c}3.4 \\
(10.6)\end{array}$ & $\begin{array}{c}9.6 \\
(18.1)\end{array}$ & $\begin{array}{c}6.5 \\
(14.3)\end{array}$ \\
\hline 2 & Mancozeb 75\%WP & 2.5 & $\begin{array}{c}10.2 \\
(18.5)\end{array}$ & $\begin{array}{c}25.1 \\
(30.0)\end{array}$ & $\begin{array}{c}17.7 \\
(24.2)\end{array}$ & $\begin{array}{c}9.7 \\
(18.1)\end{array}$ & $\begin{array}{c}12.2 \\
(20.4)\end{array}$ & $\begin{array}{c}11.0 \\
(19.2)\end{array}$ & $\begin{array}{c}2.8 \\
(9.5)\end{array}$ & $\begin{array}{c}12.5 \\
(20.5)\end{array}$ & $\begin{array}{c}7.7 \\
(15.0)\end{array}$ \\
\hline 3 & $\begin{array}{l}\text { Trifloxystrobin }+ \text { tebuconazole } \\
75 \mathrm{WG}\end{array}$ & 0.4 & $\begin{array}{c}3.2 \\
(10.2)\end{array}$ & $\begin{array}{c}7.7 \\
(15.6)\end{array}$ & $\begin{array}{c}5.5 \\
(12.9)\end{array}$ & $\begin{array}{c}7.7 \\
(15.8)\end{array}$ & $\begin{array}{c}9.9 \\
(18.4)\end{array}$ & $\begin{array}{c}8.8 \\
(17.1)\end{array}$ & $\begin{array}{c}3.4 \\
(10.4)\end{array}$ & $\begin{array}{c}9.8 \\
(18.2)\end{array}$ & $\begin{array}{c}6.6 \\
(14.3)\end{array}$ \\
\hline 4 & Propiconazole $25 \%$ EC & 1 & $\begin{array}{c}4.3 \\
(11.8)\end{array}$ & $\begin{array}{c}7.4 \\
(15.8)\end{array}$ & $\begin{array}{c}5.9 \\
(13.8)\end{array}$ & $\begin{array}{c}7.9 \\
(16.2)\end{array}$ & $\begin{array}{c}9.6 \\
(17.8)\end{array}$ & $\begin{array}{c}8.8 \\
(17.0)\end{array}$ & $\begin{array}{c}3.4 \\
(10.7)\end{array}$ & $\begin{array}{c}9.4 \\
(17.8)\end{array}$ & $\begin{array}{c}6.4 \\
(14.2)\end{array}$ \\
\hline 5 & Metiram $80 \% \mathrm{WG}$ & 2 & $\begin{array}{c}10.2 \\
(18.6)\end{array}$ & $\begin{array}{c}22.9 \\
(28.3)\end{array}$ & $\begin{array}{c}16.6 \\
(23.5)\end{array}$ & $\begin{array}{c}14.5 \\
(22.3)\end{array}$ & $\begin{array}{c}18.1 \\
(25.1)\end{array}$ & $\begin{array}{c}16.3 \\
(23.7)\end{array}$ & $\begin{array}{c}4.4 \\
(11.3)\end{array}$ & $\begin{array}{c}14.1 \\
(21.9)\end{array}$ & $\begin{array}{c}9.3 \\
(16.6)\end{array}$ \\
\hline 6 & Tebuconazole 29.5EC & 2 & $\begin{array}{c}12.7 \\
(20.9)\end{array}$ & $\begin{array}{c}22.0 \\
(27.7)\end{array}$ & $\begin{array}{c}17.4 \\
(24.3)\end{array}$ & $\begin{array}{c}12.6 \\
(20.8)\end{array}$ & $\begin{array}{c}18.4 \\
(25.1)\end{array}$ & $\begin{array}{c}15.5 \\
(22.9)\end{array}$ & $\begin{array}{c}3.0 \\
(9.8)\end{array}$ & $\begin{array}{c}12.2 \\
(20.4)\end{array}$ & $\begin{array}{c}7.6 \\
(15.1)\end{array}$ \\
\hline 7 & Propineb $70 \% \mathrm{WP}$ & 1 & $\begin{array}{c}9.6 \\
(18.0)\end{array}$ & $\begin{array}{c}18.8 \\
(25.7)\end{array}$ & $\begin{array}{c}14.2 \\
(21.8)\end{array}$ & $\begin{array}{c}16.7 \\
(24.0)\end{array}$ & $\begin{array}{c}16.5 \\
(23.9)\end{array}$ & $\begin{array}{c}16.6 \\
(23.9)\end{array}$ & $\begin{array}{c}3.2 \\
(10.2)\end{array}$ & $\begin{array}{c}12.8 \\
(21.0)\end{array}$ & $\begin{array}{c}8.0 \\
(15.6)\end{array}$ \\
\hline 8 & $\begin{array}{l}\text { Streptomycin Sulphate }+ \\
\text { Tetracycline Hydrochloride } \\
(9: 1)\end{array}$ & 0.1 & $\begin{array}{c}13.0 \\
(21.1)\end{array}$ & $\begin{array}{c}24.6 \\
(29.7)\end{array}$ & $\begin{array}{c}18.8 \\
(25.4)\end{array}$ & $\begin{array}{c}19.2 \\
(25.9)\end{array}$ & $\begin{array}{c}22.8 \\
(28.5)\end{array}$ & $\begin{array}{c}21.0 \\
(27.2)\end{array}$ & $\begin{array}{c}3.6 \\
(10.4)\end{array}$ & $\begin{array}{c}12.9 \\
(21.0)\end{array}$ & $\begin{array}{c}8.3 \\
(15.7)\end{array}$ \\
\hline 9 & Control & - & $\begin{array}{c}18.8 \\
(25.6)\end{array}$ & $\begin{array}{c}35.1 \\
(36.3)\end{array}$ & $\begin{array}{c}27.0 \\
(31.0)\end{array}$ & $\begin{array}{c}24.2 \\
(29.4)\end{array}$ & $\begin{array}{c}27.5 \\
(31.6)\end{array}$ & $\begin{array}{c}25.8 \\
(29.4)\end{array}$ & $\begin{array}{c}4.2 \\
(11.7)\end{array}$ & $\begin{array}{c}17.6 \\
(24.8)\end{array}$ & $\begin{array}{c}10.9 \\
(18.3)\end{array}$ \\
\hline & $\mathrm{CV}(\%)$ & & 10.5 & 8.9 & 6.3 & 11.3 & 11.3 & 6.8 & 26.1 & 8.9 & 9.4 \\
\hline & $\mathrm{CD}(0.05)$ & & 3.5 & 3.9 & 2.3 & 4.1 & 4.6 & 2.6 & NS & 3.1 & 2.5 \\
\hline
\end{tabular}

* Figures in parenthesis are arc sine transformed values

+ Pooled mean for two years (2011-13) 
Table.2 Influence of selected fungicides on yields in paddy over two years (2011-13)

\begin{tabular}{|c|c|c|c|c|c|c|}
\hline \multirow[t]{2}{*}{ S. No. } & \multirow[t]{2}{*}{ Treatment } & \multirow{2}{*}{$\begin{array}{l}\text { Dose } \\
\text { (g or } \\
\mathrm{ml} / \mathrm{L} \text { ) }\end{array}$} & \multicolumn{3}{|c|}{ Yield (Kg/ha.) } & \multirow{2}{*}{$\begin{array}{l}\text { Benefit: } \\
\text { cost ratio }\end{array}$} \\
\hline & & & 2011-12 & 2012-13 & $\begin{array}{l}\text { Pooled } \\
\text { Mean }\end{array}$ & \\
\hline 1 & Carbendazim 50\%WP & 1 & 3926 & 4730 & 4328 & 1.45 \\
\hline 2 & Mancozeb 75\%WP & 2.5 & 3630 & 4677 & 4153 & 1.38 \\
\hline 3 & Trifloxystrobin + tebuconazole 75WG & 0.4 & 4207 & 5082 & 4645 & 1.50 \\
\hline 4 & Propiconazole 25\% EC & 1 & 4119 & 4960 & 4539 & 1.50 \\
\hline 5 & Metiram 80\%WG & 2 & 3385 & 4229 & 3807 & 1.28 \\
\hline 6 & Tebuconazole 29.5EC & 2 & 3974 & 4651 & 4312 & 1.44 \\
\hline 7 & Propineb $70 \%$ WP & 1 & 3563 & 4671 & 4117 & 1.36 \\
\hline 8 & $\begin{array}{l}\text { Streptomycin Sulphate + Tetracycline } \\
\text { Hydrochloride }(9: 1)\end{array}$ & 0.06 & 3674 & 4578 & 4126 & 1.39 \\
\hline \multirow[t]{3}{*}{9} & Control & - & 3337 & 4361 & 3849 & 1.31 \\
\hline & $\mathrm{CV}(\%)$ & & 8.1 & 4.3 & 4.8 & \\
\hline & $\mathrm{CD}(0.05)$ & & 521 & 341 & 348 & \\
\hline
\end{tabular}

+ Pooled mean for two years (2011-13)

Table.3 Rainfall distribution at ARS, Ragolu during kharif 2011-12 and 2012-13

\begin{tabular}{|c|c|c|c|c|c|c|}
\hline \multirow[t]{3}{*}{ S. No. } & \multirow[t]{3}{*}{ Month } & \multicolumn{5}{|c|}{ Rainfall distribution } \\
\hline & & \multirow{2}{*}{$\begin{array}{c}\text { Normal } \\
\text { Rainfall } \\
(\mathbf{m m})\end{array}$} & \multicolumn{2}{|c|}{ 2011-12 } & \multicolumn{2}{|c|}{ 2012-13 } \\
\hline & & & $\begin{array}{c}\text { Actual } \\
(\mathbf{m m})\end{array}$ & $\begin{array}{c}\text { Deviation } \\
(\%)\end{array}$ & $\begin{array}{c}\text { Actual } \\
(\mathbf{m m})\end{array}$ & $\begin{array}{c}\text { Deviation } \\
(\%)\end{array}$ \\
\hline 1 & June & 134.9 & 131.2 & -2.6 & 55.1 & -59.1 \\
\hline 2 & July & 189.4 & 155.6 & -17.8 & 190.5 & +0.5 \\
\hline 3 & August & 185.1 & 251.8 & +36.0 & 113.0 & -39.0 \\
\hline 4 & September & 196.3 & 187.1 & -4.7 & 163.2 & -16.9 \\
\hline 5 & October & 182.8 & 30 & -83.6 & 78.0 & -57.3 \\
\hline 6 & November & 90.6 & 0 & -100.0 & 266.0 & +193.6 \\
\hline 7 & December & 2.6 & 12.3 & 373.1 & 0.0 & 0.0 \\
\hline \multicolumn{2}{|c|}{ Total } & 981.7 & 755.7 & -23.0 & 765.8 & -22.0 \\
\hline
\end{tabular}


Present findings are in agreement with the observations of Lore et al., (2007) and Naik et $a l$., (2016) regarding use of fungicides for minimizing the growth of fungal pathogens of rice.

During the two year study (Table 1), it was observed that propiconazole @ $1 \mathrm{ml} / \mathrm{L}$ treatment recorded pooled mean brown spot incidence of $8.8 \%$ and mean grain discoloration of $6.4 \%$ as against 25.8 and $10.9 \%$ respectively in untreated control. The treatment was found statistically at par with carbendazim and trifloxystrobin + tebuconazole treatment in terms of its efficacy against brown spot and grain discoloration. Metiram was found to be least effective in managing brown spot and grain discoloration. The findings of the present study were in agreement with Dinakaran et al., (2012) regarding effectiveness of certain fungicides against grain discoloration in rice. Lower mean brown spot and grain discoloration incidence during 2011-12 can be attributed unfavourable weather conditions as evidenced by lack of rains (Table 3 ) during flowering and grain hardening stages of crop growth.

Comparatively higher yields realized during the second year of study i.e., 2012-13 (Table 2) in spite of higher mean disease incidence (sheath rot, grain discoloration) could be attributed to favourable weather conditions as evidenced by uniform distribution of rainfall during the crop growth period, which resulted in growth promotion and enhancement of yields.

In our two year study, higher pooled mean yield (4645 kg/ha) was realized in trifloxystrobin + tebuconazole treatment (Table 2) followed by propiconazole treatment $(4539 \mathrm{~kg} / \mathrm{ha})$, although, yields obtained in propiconazole treated plots is marginally lower, the cost incurred on this chemical is comparatively lower in comparison to trifloxystrobin + tebuconazole treatment $(0.4 \mathrm{~g} / \mathrm{L})$, both the treatments recorded benefit cost ratio of 1.5:1.0. Among other fungicides evaluated, tebuconazole treatment followed by carbendazim treatment resulted in benefit cost ratio of $1.44: 1$ and 1.45:1 respectively. The study emphasizes the importance of timely chemical interventions in minimizing disease load and maximizing returns in paddy.

From the field study conducted for two years to evaluate the efficacy of selected fungicides on the development of diseases during reproductive phase in paddy, It can be concluded that foliar application of propiconazole @ $1 \mathrm{ml} / \mathrm{L}$ was found most effective followed by trifloxystrobin + tebuconazole@0.4 g/L recording a benefit cost ration of $1.5: 1.0$ in comparison to 1.28:1.0 recorded in metiram treatment. It was observed that lack of rainfall during critical stages of crop growth and prolonged dry weather during 2011-12 resulted in lower mean disease incidence (Sheath rot, brown sport and grain discoloration) and lower mean yields. It is evident that Propiconazole or trifloxystrobin + tebuconazole treatments resulted in significant reduction of sheath rot, brown spot and grain discoloration in paddy in addition to enhancing yields.

\section{References}

Dinakaran,D., Mathiyazhagan, S., Thiruvudainambi, S., Gajendran, G. and Kathiresan, G. 2012. Efficacy of Zineb + hexaconazole on the Management of Sheath Blight, Brown Spotand Grain Discoloration in Rice. Oryza-An International Journal on Rice.49(2): 144-146

Gopalakrishnan, C., Kamalakannan, A. and Valluvaparidasan, V. 2010. Effect of seed-borne Sarocladium oryzae, the incitant of rice sheath rot on rice seed 
quality. J. Plant Prot. Res. 50: 98-102.

Kumar,S. andKumar, B. 2012. Evaluation of New Fungicides And Biopesticides against Brown Spot of Rice. Vegetos: An International Journal of Plant Research and Biotechnology. 25(2): 273-275

Lore, J.S., Thind, T,S., Hunjan, M.S. and Goel, R.K. 2007. Performance of Different Fungicides against Multiple Diseases of Rice. Indian Phytopathology. 60(3): 296-301

Meera, T. and Balabaskar,P. 2012. Antifungal Activity of Botanicals against Sarocladium Oryzae Causing Rice Sheath Rot Disease. International Journal of Food, Agriculture and Veterinary Sciences. 2(1): 121-127

Naik, M.R., Akila, R. and Thiruvudainambi, S. 2016. Management Approaches for Brown Spot of Rice Caused by Bipolaris oryzae. Journal of Farm Sciences. 29(3): 370-376

Sakthivel, N. 2001. "Sheath rot disease of rice: current status and control strategies," in Major Fungal Diseases of Rice: Recent Advances eds Sreenivasaprasad S., Johnson R. (Dordrecht: Springer). 271-283

Sarkar, D., Mandal, R., Roy, P.,Taradar, J. and Dasgupta, B. 2014.Management of Brown Spot Disease of Rice by Using Safer Fungicides and some Bioagents. Bioscan. 9(1): 437-441

Sharma, L., Nagrale, D.T., Singh, S.K., Sharma, K.K. and Sinha, A.P. 2013.A Study on Fungicides Potential and Incidence of Sheath Rot of Rice Caused by SarocladiumOryzae (Sawada). Journal of Applied and Natural Science. 5(1): 24-29

Sumangala K., Patil,M.B. andShridar, D. 2011.Evaluation of Bio-Agents against Curvularia lunata, a Causal Agent of Grain Discolouration in Rice. International Journal of Plant Protection. 4(2): 260 .

\section{How to cite this article:}

Ramabhadra Raju Mudunuri and Raju, M. R. B. 2020. Effectiveness of Agrochemicals on Development of Diseases during Reproductive Phase in Paddy. Int.J.Curr.Microbiol.App.Sci. 9(10): 35-40. doi: https://doi.org/10.20546/ijcmas.2020.910.005 